\title{
Fournier's gangrene caused by penetration of a rectal cancer followed by neoadjuvant chemotherapy
}

\author{
Daigo Kobayashi ${ }^{1 *}$, Mariko Masubuchi ${ }^{2}$, Tsunenobu Takase $^{2}$, Takahiro Ichikawa ${ }^{2}$, Tomohiro Deguchi ${ }^{2}$ \\ and Toyohisa Yaguchi
}

\begin{abstract}
Background: Fournier's gangrene is a necrotizing fasciitis of the genital and perineal region. It may progress, affecting the groin, the thigh, or even the abdominal wall.

Despite adequate treatment (debridement and antibiotics), the mortality rate is very high, reaching 20-35\%. Fournier's gangrene caused by penetration of a rectal cancer followed by neoadjuvant chemotherapy is very rare. We report this case with a review of the literature.

Case presentation: A 68-year-old man visited the emergency room due to perineal pain during which he accepted the chemotherapy for locally advanced rectal cancer. Abdominal $C T$ scan showed extensive emphysema in the scrotum and gluteus maximus muscle. We diagnosed as Fournier's gangrene caused by penetration of a rectal cancer. We performed debridement, left orchiectomy, transverse colostomy with double orifices. Post-operative day 30, we performed abdominoperineal resection. We performed CapeOX therapy eight courses as adjuvant chemotherapy. The patient had no recurrence for 1 year and 2 months after the operation.

Conclusions: Going forward, knowledge gained from this case will increase the opportunity to perform neoadjuvant chemotherapy for locally advanced rectal cancer. In medical treatment, we must put the possibility of Fournier's gangrene in mind and treat as soon as possible.
\end{abstract}

Keywords: Fournier's gangrene, Locally advanced rectal cancer, Neoadjuvant chemotherapy

\section{Background}

Fournier's gangrene is a necrotizing fasciitis of the genital and perineal region. It may progress, affecting the groin, the thigh, or even the abdominal wall.

Despite adequate treatment (debridement and antibiotics), the mortality rate is very high, reaching $20-35 \%$ [1]. There has been no report on the onset of Fournier's gangrene caused by penetration of a rectal cancer followed by neoadjuvant chemotherapy. We report this case with a review of the literature.

\footnotetext{
* Correspondence: mmmeerryyyy2101@yahoo.co.jp

'Department of Surgery, Komaki City Hospital, 1-20 Joubushi, Komaki, Aichi 485-8520, Japan

Full list of author information is available at the end of the article
}

\section{Case presentation}

A 68-year-old Japanese man presented at our hospital for evaluation and treatment of rectal cancer. He had no history of rectal cancer. He had been diagnosed with rectal cancer using colonoscopy for screening of rectal bleeding; following biopsy, the tumor was confirmed to be moderately differentiated adenocarcinoma. Barium enema showed a filling defect at the rectum below the peritoneal reflection (Fig. 1). Contrast-enhanced CT (CECT) revealed swollen lateral lymph nodes (Fig. 2). We diagnosed him as having rectal cancer cT4aN1M0 clinical stageIIIa (UICC 8th). We decided to perform neoadjuvant chemotherapy for locally advanced rectal cancer for the purpose of the prevention of postoperative local recurrence. We performed CapeOX therapy 1 course until the RAS results were out. Since the RAS gene was confirmed as the wild-type, we changed the 


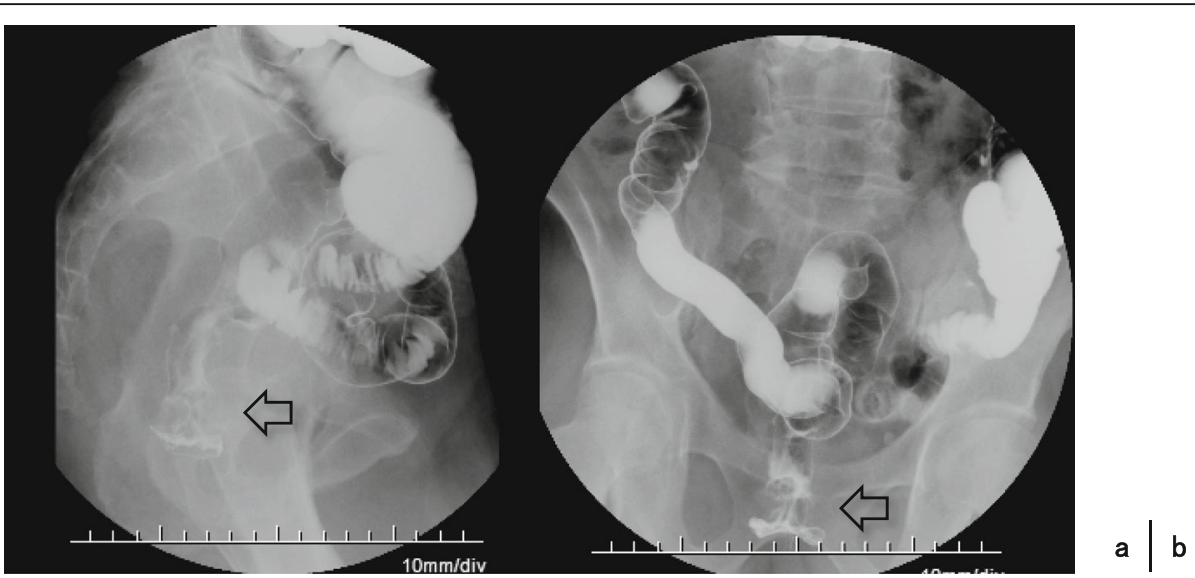

Fig. 1 Barium enema showed the apple core sign at the rectum below the peritoneal reflection (arrow)

regimen and performed FOLFOX + cetuximab therapy 1 course to reduce the tumor size. The reason why we chose cetuximab is we can perform chemotherapy with cetuximab until just before surgery. On day 14, he visited the emergency room due to perineal pain. Physical findings showed BT $38.0{ }^{\circ} \mathrm{C}$, HR $117 / \mathrm{min}$, BP $79 /$ $57 \mathrm{mmHg}$, tenderness, redness, and swelling of the perineum and scrotum (Fig. 3). He had no tenderness of the abdomen. CECT revealed extensive emphysema in the scrotum and gluteus maximus muscle (Fig. 4). We diagnosed as Fournier's gangrene caused by penetration of a rectal cancer. We performed debridement, left orchiectomy, transverse colostomy with double orifices. Abscess cultures yielded Escherichia coli. Intravenous antimicrobial treatment was administered using cefmetazole $(1 \mathrm{~g}$ every $6 \mathrm{~h}$ ).

After the first operation, we cleaned the wound every day. Because his right testis was in poor condition, we performed right orchiectomy under local anesthesia on postoperative day (POD) 7. Once the granulation tissue had formed (Fig. 5), we performed abdominoperineal resection (APR) and dissected the left lateral lymph nodes. on POD30 (Fig. 6). The amount of blood loss was $320 \mathrm{ml}$, and the operation time was $269 \mathrm{~min}$. Pathological findings were type3, $35 \times 30 \mathrm{~mm}$, tub2, ly1, v2, ypT3N1a(263), and M0 Stage IIIa (UICC 8th). Histological grade was 1a (RECIST v1.1). The tumor left side wall was thin. Because the effect of chemotherapy was poor, we diagnosed as Fournier's gangrene caused by penetration of rectal cancer.

After the second operation, we cleaned the wound every day. He left the hospital on POD59. On POD92, the wound was healed like that in the picture (Fig. 7). Since he wanted to leave the hospital, we showed him the treatment procedure for scar healing. We performed CapeOX therapy eight courses as adjuvant chemotherapy. The patient had no recurrence for 1 year and 2 months after the operation.

\section{Discussion}

Fournier's gangrene (FG) is a rare, life-threatening, necrotizing fasciitis that usually involves the perineal or genital areas. It was described by Baurienne in 1764 and formally named by Fournier in 1883 [2]. Prompt

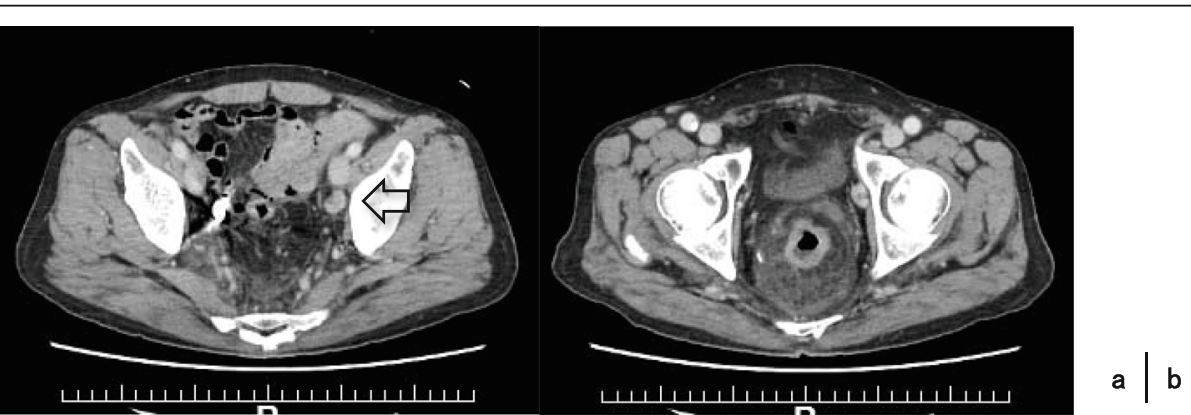

Fig. 2 a The left-sided lateral lymph nodes were swollen (arrow). b Fat concentration was increased 


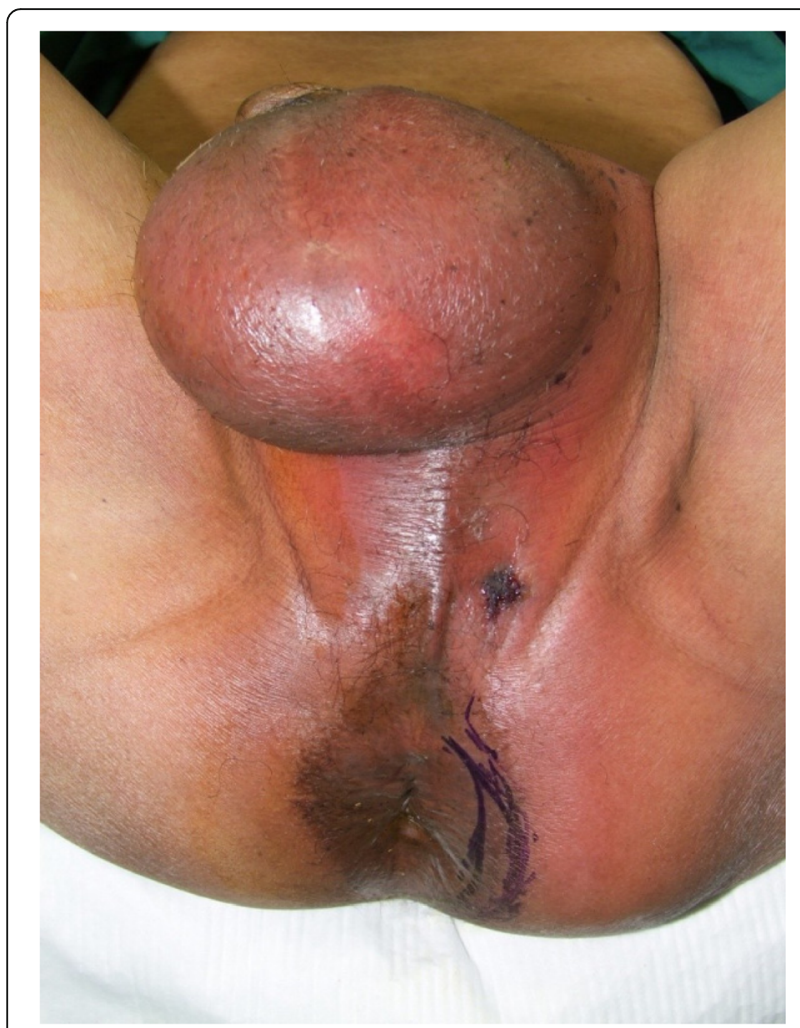

Fig. 3 The perineum and scrotum was swollen

identification of this deadly disease is fundamental for appropriate treatment. Despite adequate treatment, the mortality rate is very high, reaching 20-35\% [1].

Accepted predisposing factors for FG are poor perfusion (peripheral vascular disease), hypertension, renal insufficiency, trauma, diabetes mellitus, malnutrition, smoking, obesity, immunocompromised status, intravenous drug abuse, malignancy, and spinal cord injury [3,

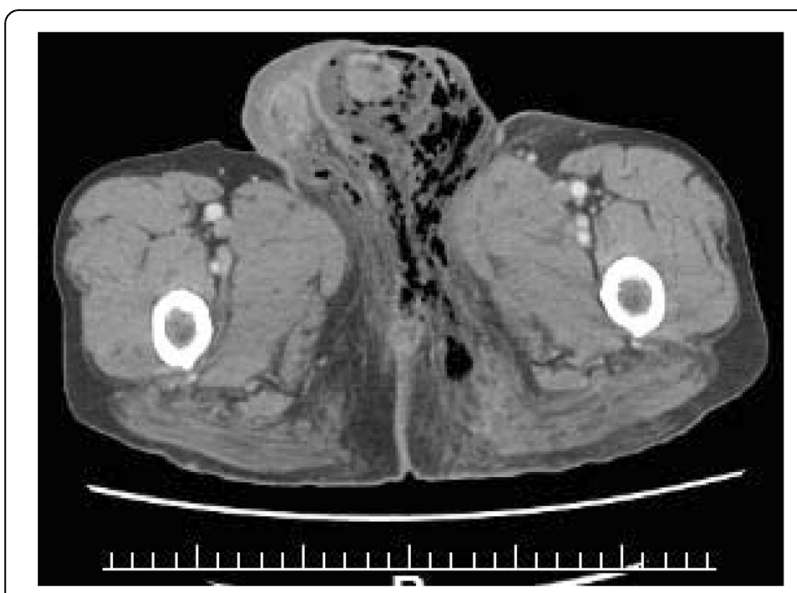

Fig. 4 Extensive emphysema in the scrotum and gluteus maximus muscle
4]. Old age is not a predisposing factor; however, elderly patients with poor self-care and poor nutritional status are more susceptible. Female to male ratio varies significantly. The lower incidence in women is ascribed to better drainage of the perineal region through vaginal secretions [5].

There are three development paths: (1) trauma surrounding the perineum, (2) progress along the muscle membrane surface of the infected urinary tract, and (3) infection of the perianal and retroperitoneum [4].

Treatment with broad-spectrum antibiotic coverage to include staphylococci, streptococci, Enterobacteriaceae, and anaerobes should be promptly initiated. However, aggressive surgical management remains the mainstay of treatment. This includes wide excision of all necrotic tissue down to bleeding tissues [6]. Oftentimes, repeated operative debridements may be needed to sufficiently debride all involved tissue.

Although perforation of rectal cancer after treatment with bevacizumab or radiation therapy has been well documented, reports of spontaneous perforation of rectal cancer presenting as FG are rare. There have been some reports on the onset of FG caused by penetration of a rectal cancer followed by neoadjuvant chemotherapy. In the world, 35 cases of FG caused by penetration of rectal cancer, including the present case, have been reported (Table 1). The median age in the Japanese group was 61.1 years with a male to female ratio of 31:4. Nine $(25.7 \%)$ of 35 patients had diabetes mellitus (DM) as a comorbidity. DM was considered a risk factor for FG in the Japanese group as well. Debridement was performed in 32 of 35 patients. It is considered to be essential thorough debridement. Colostomy, including APR and total pelvic exenteration (TPE), was created in 30 of 35 patients. Only five patients were able to avoid a colostomy. With respect to colostomy for FG, this does not have just one point of view [7]. But we considered that colostomy was an effective treatment for FG caused by penetration of rectal cancer or anal canal cancer. Treatment for rectal cancer with FG was APR for 13 patients, TPE for five patients, and chemotherapy alone for six patients. With respect to outcome, seven (20\%) patients were dead in the hospital. Seven (20\%) patients were treated with preoperative chemotherapy.

In our case, we promptly diagnosed as FG caused by penetration of a rectal cancer followed by neoadjuvant chemotherapy, and performed debridement and colostomy as soon as possible. After that, we performed APR and got a good prognosis.

The disease is life-threatening and has a high mortality rate. Therefore, prompt diagnosis and treatment (debridement and antibiotics) is recommended. Going forward, knowledge gained from this case will increase the opportunity to perform neoadjuvant chemotherapy for 


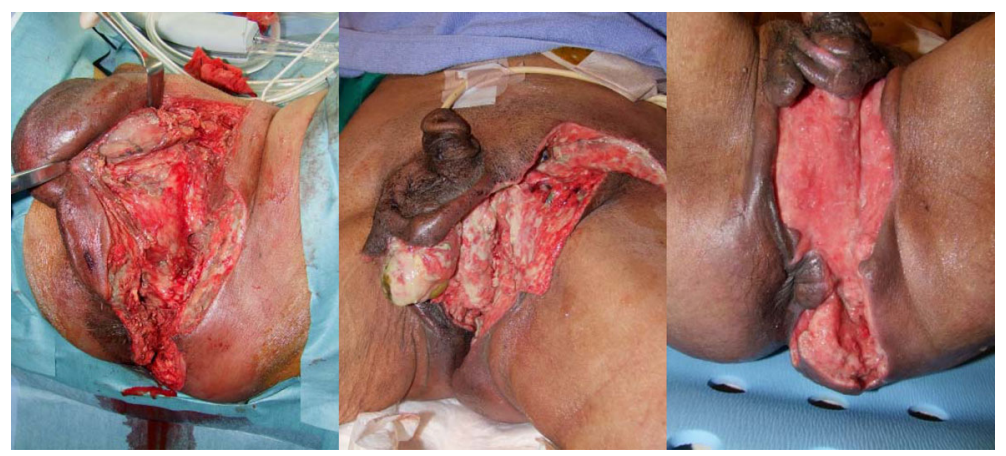

$\mathbf{a}|\mathbf{b}| \mathbf{c}$

Fig. 5 Debridement, left orchiectomy, transverse colostomy with double orifices (a). We cleaned the wound every day (b). The granulation tissue was formed (c)
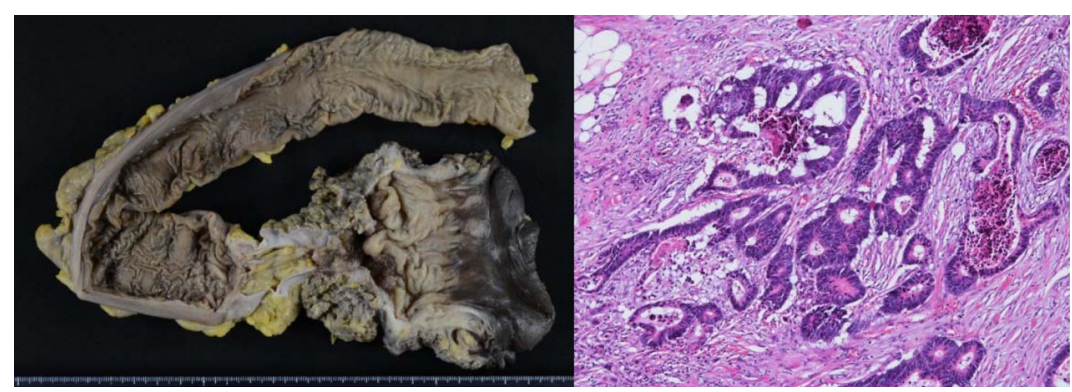

a $\mid \mathbf{b}$

Fig. 6 Resected specimen (a). Histological effect judgment was grade 1a (RECIST v1.1) (b)

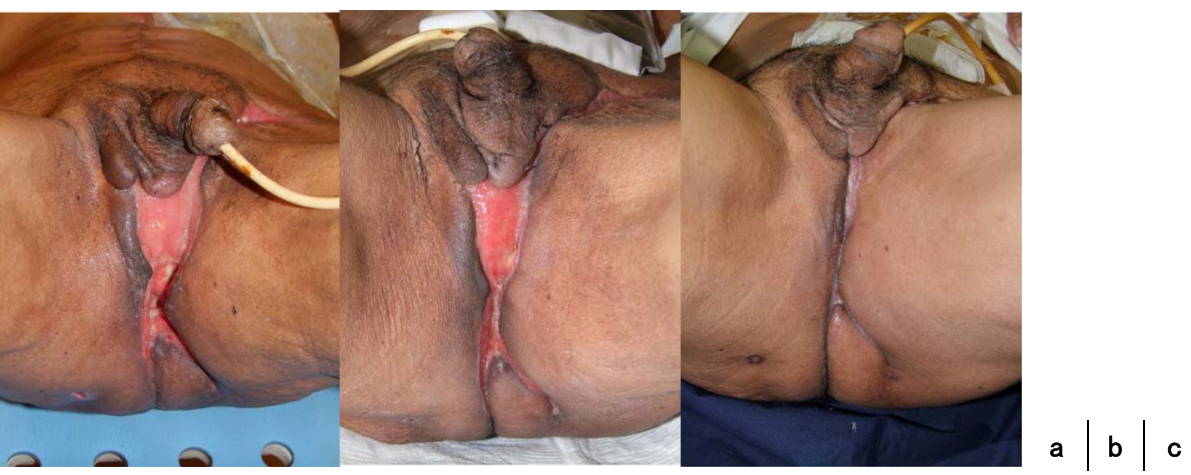

Fig. 7 Cleaned the wound every day (a). At discharge (b). Healing (c) 
Table 1 Clinical data of patients of Fournier's gangrene caused by penetration of rectal cancer

\begin{tabular}{|c|c|c|c|c|c|c|c|c|c|c|c|c|}
\hline Case & Author & Year & Age & Sex & $\mathrm{DM}$ & Origin & Histology & $\begin{array}{l}\text { 1st } \\
\text { operation }\end{array}$ & $\begin{array}{l}\text { 2nd } \\
\text { operation }\end{array}$ & $\begin{array}{l}\text { 3rd } \\
\text { operation }\end{array}$ & $\begin{array}{l}\text { Preoperative } \\
\text { chemotherapy }\end{array}$ & Outcome \\
\hline 1 & Futamura [8] & 1995 & 56 & $M$ & - & $\mathrm{Rb}$ & tub1 & 1 & $\mathrm{D}$ & APR & - & $\begin{array}{l}\text { Alive (4 years and } \\
7 \text { months) }\end{array}$ \\
\hline 2 & Nakao [9] & 1999 & 51 & M & + & Rab & tub1 & $\mathrm{D}$ & C & & - & Unknown \\
\hline 3 & Fujisawa [10] & 1999 & 75 & M & - & $\mathrm{Rb}$ & Unknown & । & $\mathrm{D}$ & & - & Death (6 days) \\
\hline 4 & Saito [11] & 2000 & 60 & M & - & Rab & tub1 & $\mathrm{D}$ & C & $\begin{array}{l}\text { TPE + } \\
\text { anaplasty }\end{array}$ & - & Alive ( 1 year) \\
\hline 5 & Noriyuki [12] & 2003 & 58 & M & + & Rab & tub2 & । & $D+C$ & & - & $\begin{array}{l}\text { Alive (1 year and } \\
2 \text { months) }\end{array}$ \\
\hline 6 & Shino[13] & 2003 & 62 & M & - & $\mathrm{RbP}$ & tub2 & I & $D+C$ & APR & - & Alive (3 months) \\
\hline 7 & Enomoto[14] & 2006 & 35 & M & - & Rab & tub1 & $\mathrm{D}$ & APR & & - & Alive (3 months) \\
\hline 8 & Moriwaki [15] & 2007 & 30 & M & - & Rab & tub2 & $1+C$ & APR & $\begin{array}{l}\mathrm{D}+ \\
\text { anaplasty }\end{array}$ & - & Death (11 months) \\
\hline 9 & Kojima [16] & 2007 & 56 & M & + & $\mathrm{Rb}$ & tub2 & $D+C$ & TPE & & - & Alive (4 months) \\
\hline 10 & Morohashi [17] & 2008 & 60 & M & + & $\mathrm{Rb}$ & tub1 & $\mathrm{D}$ & $D+C$ & & - & Death (2 months) \\
\hline 11 & Ishibashi [18] & 2009 & 80 & $\mathrm{~F}$ & - & $\mathrm{Rb}$ & Unknown & $\mathrm{D}$ & Anaplasty & & - & Alive (2 months) \\
\hline 12 & Suzuki [19] & 2009 & $60 \mathrm{~s}$ & M & - & $\mathrm{Rb}$ & tub1 & $\mathrm{D}$ & $D+C$ & & - & Death (2 months) \\
\hline 13 & Moslemi [20] & 2009 & 48 & M & Unknown & Unknown & Unknown & $1+C$ & & & - & Alive (unknown) \\
\hline 14 & Yamazaki [21] & 2010 & $50 \mathrm{~s}$ & M & - & $\mathrm{Rb}$ & tub2 & $\mathrm{D}$ & APR & Anaplasty & - & Alive (1 month) \\
\hline 15 & Onizuka [22] & 2010 & 55 & M & - & Rs-b & Unknown & $\mathrm{D}$ & $D+C$ & & - & $\begin{array}{l}\text { Alive (1 year and } \\
2 \text { months) }\end{array}$ \\
\hline 16 & Tanaka [23] & 2010 & 52 & $F$ & + & $\mathrm{Rb}$ & muc & $\mathrm{D}$ & $D+C$ & APR & - & Alive (5 months) \\
\hline 17 & Matsuda [24] & 2010 & 51 & M & - & Unknown & Unknown & $\mathrm{D}$ & C & & - & Death (10 months) \\
\hline 18 & Matsuda [24] & 2010 & 69 & M & - & Unknown & Unknown & $D+C$ & & & - & $\begin{array}{l}\text { Alive (1 year and } \\
10 \text { months) }\end{array}$ \\
\hline 19 & Watanabe [25] & 2013 & 77 & M & - & $\mathrm{Rb}-\mathrm{P}$ & tub1 & $D+C$ & & & - & Death (70 days) \\
\hline 20 & Takahashi [26] & 2013 & 79 & M & + & Rab & tub1 & $D+C$ & $\begin{array}{l}\text { APR + } \\
\text { anaplasty }\end{array}$ & & - & Alive (unknown) \\
\hline 21 & Momma [27] & 2013 & 79 & M & - & $\mathrm{Rb}-\mathrm{P}$ & Unknown & । & $\mathrm{D}$ & & + & Alive ( 1 year) \\
\hline 22 & Kawagoe [28] & 2014 & 72 & M & - & $\mathrm{Rb}$ & Unknown & $\mathrm{D}$ & $D+C$ & & - & Alive (6 months) \\
\hline 23 & Ishikawa [29] & 2015 & 74 & M & - & $\mathrm{Rb}$ & tub2 & $\mathrm{D}$ & TPE & & - & $\begin{array}{l}\text { Alive ( } 4 \text { years } \\
10 \text { months) }\end{array}$ \\
\hline 24 & Tsutsuyama [30] & 2015 & 61 & M & - & $\mathrm{Rb}$ & tub2 & $D+C$ & APR & & - & Alive (3 months) \\
\hline 25 & Abe [31] & 2015 & 71 & $\mathrm{~F}$ & - & $\mathrm{Rb}$ & tub2 & $D+C$ & APR & & - & $\begin{array}{l}\text { Alive ( } 3 \text { years } \\
6 \text { months) }\end{array}$ \\
\hline 26 & Tanaka [32] & 2016 & 67 & M & + & $\mathrm{Rb}$ & tub2 & $D+C$ & APR & & - & Alive (1 year) \\
\hline 27 & Kuroda [33] & 2016 & 63 & M & + & $\mathrm{Rb}$ & tub2 & $D+C$ & APR & & - & $\begin{array}{l}\text { Alive ( } 2 \text { years and } \\
9 \text { months) }\end{array}$ \\
\hline 28 & Yoshino [34] & 2016 & 65 & M & Unknown & Unknown & Unknown & $D+C$ & $\begin{array}{l}\text { TPE + } \\
\text { anaplasty }\end{array}$ & & - & Alive (108 days) \\
\hline 29 & Suzuki [35] & 2017 & 64 & M & + & $\mathrm{RaRb}$ & tub2 & $\mathrm{D}$ & APR & & - & $\begin{array}{l}\text { Death ( } 3 \text { years } \\
\text { and } 10 \text { months) }\end{array}$ \\
\hline 30 & Koyama [36] & 2017 & 66 & M & - & Unknown & Unknown & I & & & + & Alive (12 days) \\
\hline 31 & Koyama [36] & 2017 & 63 & M & Unknown & Unknown & muc & । & & & + & Alive (18 days) \\
\hline 32 & Sawayama [37] & 2017 & 66 & M & Unknown & Unknown & Unknown & $\mathrm{D}$ & TPE + anaplasty & & + & Alive (unknown) \\
\hline 33 & Fukuhisa [38] & 2017 & 73 & M & Unknown & Unknown & Unknown & $D+C$ & & & + & Alive (50 days) \\
\hline 34 & Pittaka [39] & 2018 & 24 & $\mathrm{~F}$ & Unknown & Unknown & Unknown & $\mathrm{D}$ & & & + & Alive ( 1 year) \\
\hline 35 & Our case & 2018 & 68 & M & - & $\mathrm{Rb}$ & tub2 & $D+C$ & APR & & + & $\begin{array}{l}\text { Alive (1 year and } \\
2 \text { months) }\end{array}$ \\
\hline
\end{tabular}


locally advanced rectal cancer. In medical treatment, we must put the possibility of Fournier's gangrene in mind and treat as soon as possible.

\section{Conclusions}

We reported the first case of Fournier's gangrene caused by penetration of a rectal cancer followed by neoadjuvant chemotherapy with a review of literature.

\section{Abbreviations}

APR: Abdominoperineal resection; CECT: Contrast-enhanced computed tomography; DM: Diabetes mellitus; FG: Fournier's gangrene; POD: Postoperative day; TPE: Total pelvic exenteration

\section{Availability of data and materials}

We wish to share our data and materials.

\section{Authors' contributions}

DK is involved in this patient's first and second operation. He also drafted and revised the manuscript. MM was an attending surgeon who was involved in this patient's management. TT was involved in this patient's second operation. TI was involved in this patient's management in hospital days. TD was involved in this patient's first operation. TY was involved in drafting and revising this manuscript. All authors read and approved the final manuscript.

\section{Ethics approval and consent to participate}

Not applicable.

\section{Consent for publication}

Written informed consent was obtained from the patient for the publication of this case report and any accompanying images.

\section{Competing interests}

The authors declare that they have no competing interests.

\section{Publisher's Note}

Springer Nature remains neutral with regard to jurisdictional claims in published maps and institutional affiliations.

\section{Author details}

'Department of Surgery, Komaki City Hospital, 1-20 Joubushi, Komaki, Aichi 485-8520, Japan. ²Department of Surgery, Kainan Hospital, 396 Minamihonden, Maegasu-cho, Yatomi, Aichi 498-8502, Japan.

Received: 15 May 2018 Accepted: 10 September 2018

Published online: 26 September 2018

\section{References}

1. Chan CC, Williams M. Fournier gangrene as a manifestation of undiagnosed metastatic perforated colorectal cancer. Int Surg. 2013;98:43-8.

2. Fournier AJ. Overwhelming gangrene [in French]. Sem Med. 1883;3:345.

3. Eke N. Fournier's gangrene: a review of 1726 cases. Br J Surg. 2000;87(6): $718-28$.

4. Jones RB, Hirschmann JV, Brown GS, Tremann JA. Fournier's syndrome: necrotizing subcutaneous infection of the male genitalia. J Urol. 1979;122(3): 279-82.

5. Pierlesky EO, Tarik S, Karim IM, Imane T, Said AL, Khalid M, et al. Fournier gangrene: rare complication of rectal cancer. Pan African MJ. 2015:20:288.

6. Fajdic J, Gotovac N, Hrgovic Z. Fournier gangrene: our approach and patients. Urol Int. 2011;87(2):186-91

7. Basoglu M, Ozbey I, Atamanalp SS, Yildirgan MI, Aydinli B, Polat O, et al. Management of Fournier's gangrene: review of 45 cases. Surg Today. 2007; 37:558-63.

8. Futamura N, Kano N, Fukuhara N, Komura Y, Miyamoto K, Maeda H, et al. A case of rectal cancer with Fournier's gangrene. J Jpn Surg Assoc. 1995;56(2): 399-402.
9. Nakao T, Inatsugi N, Yoshikawa S, Takamura H, Masuda T, Nakano H. Fournier's gangrene caused by penetration of rectal cancer in an adult. J Jpn Surg Assoc. 1999;60(12):3293-6.

10. Fujisawa M, Maruyama T, Kojima K, Fukusawa M, Beppu T, Futagawa S. A case of Fournier's gangrene associated with rectal cancer. J J.jpn Surg Assoc. 1999;60(6):1583-6.

11. Saito C, Yamada A, Kosaka K, Konno M, Toyabe S. A case of Fournier's gangrene caused by skin perforation due to rectal cancer invasion. J Jpn PRS. 2000:20:31-5.

12. Noriyuki T, Shimatani $K$, Shintaku S, lida M, Moriuchi $H$, Sakamoto $Y$, et al. A case of advanced rectal cancer with Fournier's gangrene. Dig Surg. 2003;26: $371-5$.

13. Shiino $Y$, Ozaki S. A case of an anal canal cancer manifesting as an extended Fournier's gangrene. Jpn J Gastroenterol Surg. 2003;36(11):1641-5.

14. Enomoto T, Sumiyama Y, Nagao J, Saita Y, Watanabe M, Asai K, et al. A case of Fournier's gangrene caused by rectal cancer. J Jpn Coll Surg. 2006;31(2): 231-4.

15. Moriwaki Y, Yamamoto T, Anse M, Sugiyama M. A case of Fournier's gangrene due to advanced rectal treated by central department including several specialists. JCLS. 2007;62(6):845-8.

16. Kojima Y, Kamano T, Sakamoto K, Matsuda M, Sengoku H, Takita N, et al. A case of Fournier's gangrene caused by perforation of rectal carcinoma. Jpn 」 Gastroenterol Surg. 2007:40(4):485-90.

17. Morohashi H, Yamada K, Matsuura O, Yamazaki S, Fujita M. A case of Fournier's gangrene with rectal cancer. J Jpn Surg Assoc. 2008;69(7):1823-7.

18. Ishibashi $Y$, Ito $Y$, Wakabayashi K. A case of Fournier's gangrene caused by penetration of rectal carcinoma. J Jpn Surg Assoc. 2009;70(6):1772-6.

19. Suzuki Y, Morohashi H, Yamada K, Matsuura O, Yamazaki S, Fujita M. Two cases of Fournier's gangrene with rectal cancer. Med J Mutsu Gen Hosp. 2009:14:9-13.

20. Moslemi MK, Sadighi Gilani MA, Moslemi AA, Arabshahi A. Fournier gangrene presenting in a patient with undiagnosed rectal adenocarcinoma: a case report. Cases J. 2009;2:9136.

21. Yamazaki T, Goi T, Nakazawa T, Otsuki T, Katayama N, Yamaguchi A. A case of Fournier's gangrene with rectal cancer. Surgery. 2010;72(10):1125-9.

22. Onizuka K, Ito S, Tanoue T, Yamauchi M, Yamayoshi T, Kidokawa H. Three cases of Fournier's gangrene. J Jpn Surg Assoc. 2010;71(12):3219-22.

23. Tanaka N, Tanabe A, Yamamoto J, Kusumoto K. A case of Fournier's gangrene caused by rectal carcinoma. Jpn J Surg Wound Care. 2010;2 102-6.

24. Matsuda K, Akahane T, Shimada R, Horiuchi A, Shibuya H, Nakamura K, et al. Fournier's syndrome. Stomach Intestine. 2010;45(8):1387-91.

25. Watanabe $H$, Tonouchi H, Noguchi T, Imaoka H, Yokoe T, Ojima E, et al. A case of Fournier's gangrene caused by penetration of rectal carcinoma. J Jpn Soc Surg Infect. 2013;10(1):149-53.

26. Takahashi K, Tsukamoto S, Takahashi S, Saito M, Ohkohchi N, Hirayama K. A case of Fournier's gangrene caused by rectal cancer that was reconstructed using a rectus abdominis myocutaneous flap. J Jpn Surg Assoc. 2013;71(4): 1086-91.

27. Momma T, Kikuchi D, Watanabe Y, Onozawa H, Suzuki S, Nakamura I, et al. A case of anal canal cancer which developed Fournier's syndrome after chemoradiotherapy. J Jpn Soc Coloproctol. 2013;66:358-63.

28. Kawagoe K, Hamasaki K, Ishikawa H, Fukuoka H, Taniguchi D, Shibuya A, et al. Management of Fournier's gangrene caused by rectal cancer for early chemotherapy. J Japan Soc Coloproctol. 2014;67:448-53.

29. Ishikawa T, Honma S, Shibasaki S, Kawamura H, Takahashi N, Taketomi A. A long-term relapse free survival case of Fournier's gangrene by rectal carcinoma. J Jpn Coll Surg. 2015;40(5):938-43.

30. Tsutsuyama M, Komori K, Kimura K, Kinoshita T, Shimizu Y. Fournier's gangrene caused by penetration of a rectal cancer with uncontrolled gastric ulcer bleeding. Jpn J Gastroenterol Surg. 2015;48(10):862-8.

31. Abe K, Kameyama H, Shimada $Y$, Yamada S, Soma D, Yagi R. A case of rectal carcinoma with recurrence around the drainage site complicated by Fournier's gangrene. Jpn J Cancer Chemother. 2015:42(12):2291-3.

32. Tanaka H, Suzuki N, Tomochika S, Inoue Y, Kuwahara T, Sakamoto K, et al. Use of a posterior thigh flap with the gluteus maximus for perineal reconstruction-a case of Fournier's gangrene with rectal cancer. Jpn J Cancer Chemother. 2016:43(12):1821-3.

33. Kuroda M, Ikeda E, Tsuji H, Yokoyama N, Takagi S, Yamano T, et al. A case of rectal cancer with Fournier gangrene. J Abdom Emerg Med. 2016;36(4): 797-802. 
34. Yoshino Y, Fukahashi K, Okada R, Miura Y, Suzuki T, Koda T, et al. Severe Fournier's gangrene in a patient with rectal cancer: case report and literature review. World J Surg Oncol. 2016;14(1):234.

35. Suzuki Y, Hiramatsu S, Seki T, Ikuta Y, Ozaki Y, Arai T. A case of rectal cancer causing Fournier's gangrene and progressing to septic shock. J Abdom Emerg Med. 2017:37(3):515-9.

36. Koyama M, Kitazawa M, Ehara T, Yamamoto Y, Suzuki A, Miyagawa Y, et al. Two cases of Fournier's gangrene that occurred during chemotherapy for rectal cancer. Jpn J Cancer Chemother. 2017;44(2):169-71.

37. Sawayama H, Miyanari N, Sugihara H, Iwagami S, Mizumoto T, Kubota T, et al. A fascia lata free flap in pelvic exentration for Fournier gangrene due to advanced rectal cancer: a case report. Surg Case Rep. 2017;3(1):74.

38. Fukuhisa H, Baba K, Kita Y, Tanabe H, ljichi T, Mori S, et al. A case of Fournier's gangrene due to perforation of lower rectal cancer during chemotherapy. Gan To Kagaku Ryoho. 2017:44(10):935-7.

39. Pittaka M, Georgiou C, Polyviou P, Kountourakis P, Loizou P, Constantinou I, et al. Fournier Gangrene in a patient receiving chemo-radiation for rectal cancer. Oxf Med Case Reports. 2018;2018(2):omx101.

\section{Submit your manuscript to a SpringerOpen ${ }^{\circ}$ journal and benefit from:}

- Convenient online submission

- Rigorous peer review

- Open access: articles freely available online

- High visibility within the field

- Retaining the copyright to your article

Submit your next manuscript at $\boldsymbol{\nabla}$ springeropen.com 